\title{
Peramalan Multivariat untuk Menentukan Harga Emas Global
}

\author{
David Christian ${ }^{1}$, Siana Halim ${ }^{*}$
}

\begin{abstract}
Gold is one of the most enticing commodities and a popular kind for investment. Gold's price is allegedly influenced by other factors such as US Dollar, oil's price, inflation rate, and stock exchange so that its model is not only affected by its previous value. The aim of this research is to determine the best forecasting model and the influencing factors to gold's price. Firstly, this research reviewed the univariate modeling as a benchmark and comparison to the multivariate model. The univariate time series was modeled using the ARIMA model. The model indicated that the fluctuation of the gold prices was following the white noise. Secondly, the multivariate model was built using the vector error correction model (VECM) with oil's price, US Dollar and Dow Jones indices, and inflation rate as predictors. Research's result showed that the VECM was able to model the gold's price well and all factors under investigation affected the gold's price. US Dollar and oil's price negatively correlated with gold's price, while the inflation rate positively correlated. Dow Jones Index positively correlated with gold's price only at the first two periods.
\end{abstract}

Keywords: ARIMA; Cointegration; VAR; VECM.

\section{Pendahuluan}

Investasi emas dapat dilakukan dengan berbagai bentuk/wujud seperti: emas batangan, emas perhiasan, koin emas, sertifikat emas, saham perusahaan emas. Banyak kalangan bahkan hampir setiap negara di dunia menyimpan kekayaan mereka dalam bentuk emas. Amerika Serikat pada tahun 2015 menyimpan kekayaan dalam bentuk emas seberat 8.133 ton, disusul Jerman (3.381 ton), Italia (2.435 ton), Prancis (2.435 ton), dan Cina (1.762 ton) (Holmes [1]). Kecenderungan orang menyimpan kekayaan mereka dalam bentuk emas dikarenakan kecenderungan harga emas yang meningkat dalam jangka panjang serta kemampuan emas dalam mengatasi gejolak inflasi (Kusuma [2]). Bagaimanapun juga, kecenderungan tersebut tidak serta merta menjadikan emas sebagai pilihan utama dalam berinvestasi. Prediksi atau peramalan akan nilai tukar emas dimasa mendatang menjadi pertimbangan sebelum membuat keputusan untuk berinvestasi.

Sebuah penelitian yang dilakukan oleh Botha [3] mengenai perilaku harga emas menyatakan bahwa pergerakan harga emas independen terhadap harga masa lalu dari emas. Shankari dan Manimaran [4] menemukan fakta dalam penelitian mereka bahwa harga emas mengikuti bentuk random walk dimana penelitian ini dilakukan terhadap harga emas secara khusus di India. Kedua penelitian tersebut dilakukan dengan menggunakan univariate time series modeling pada kurun waktu yang berbeda dan

\footnotetext{
${ }^{1}$ Fakultas Teknologi Industri, Program Studi Teknik Industri, Universitas Kristen Petra, Jl. Siwalankerto 121-131 Surabaya 60238, Indonesia. Email: m25413002@john.petra.ac.id, halim@ petra.ac.id.

* Penulis korespondensi
}

menghasilkan kesimpulan yang serupa. Kedua penelitian ini menyatakan bahwa harga emas yang diteliti tidak dapat dimodelkan dengan hanya menggunakan data emas itu sendiri.

Harga suatu komoditas tidak dipungkiri dipengaruhi oleh faktor-faktor lain disamping nilai historisnya sendiri seperti harga barang substitusi, inflasi, kondisi ekonomi, politik, dan lain sebagainya. Sepanek [5] menyatakan bahwa harga emas dipengaruhi oleh beberapa faktor diantaranya US Dollar dan tingkat inflasi. Faktor lain yang turut mempengaruhi harga emas adalah kondisi ekonomi dan politik (sahabat pegadaian [6]). Seorang pengamat pasar, Gilroy [7] menyatakan bahwa terdapat hubungan terbalik antara harga emas dan minyak dunia. Pengaruh faktor-faktor tersebut dapat dimodelkan secara ilmiah menggunakan pemodelan multivariat yang akan dibahas pada penelitian ini.

Penelitian terdahulu telah memodelkan harga emas secara univariat dimana hanya menggunakan harga emas dalam melakukan pemodelan. Pemodelan univariat tidak dapat merepresentasikan adanya pengaruh dari variabel-variabel lain terhadap harga emas. Pengkajian akan adanya pengaruh dari variabel lain dapat dilakukan dengan melakukan pemodelan multivariat.

Pada makalah ini harga emas akan dimodelkan secara multivariat, yang diawali dengan kajian ulang pemodelan harga emas dengan menggunakan univariate modeling. Kajian ulang ini dimaksudkan untuk melihat apakah pernyataan Botha [3], Shankari dan Manimaran [4] juga berlaku di sini. Pemodelan multivariat dilakukan dengan tujuan untuk mendapatkan model yang lebih akurat serta 
mengetahui besaran pengaruh dari variabelvariabel lain terhadap harga emas. Pemodelan multivariat terhadap harga emas dilakukan dengan memasukkan faktor-faktor yang berpengaruh untuk mendapatkan model yang lebih baik. Faktor-faktor yang akan dianalisis dalam penelitian ini adalah US Dollar, tingkat inflasi, indeks saham gabungan (sebagai gambaran dari kondisi politik dan ekonomi), serta harga minyak mentah dunia.

\section{Metode Penelitian}

\section{Pemodelan Univariat Time Series}

Secara garis besar, pemodelan prediksi harga emas ini dilakukan pertama-tama dengan melihat apakah data bersifat stasioner atau tidak. Uji stasioneritas dilakukan dengan menggunakan augmented Dickey Fuller test. Bila data tersebut stastioner maka model ARMA(p,q) akan diterapkan pada data yang dimiliki, namun bila tidak stasioner maka model $\operatorname{ARIMA~(p,d,q)~yang~akan~digunakan.~}$

Secara ringkas metode-metode yang digunakan dapat dipaparkan sebagai berikut:

\section{Augmented Dickey Fuller Test}

Augmented Dickey Fuller test adalah salah satu jenis tes untuk menguji stasioneritas suatu time series. Pengujian ini dilakukan dengan meregresikan difference pertama dari sebuah time series terhadap lag pertama dari time series dan $k$-lag dari difference pertama sebuah time series. Persamaan regresi dapat dilihat pada (1).

$$
\begin{aligned}
& Y_{t}-Y_{t-1}=a Y_{t-1}+\phi_{1}\left(Y_{t-1}-Y_{t-2}\right)+\ldots+\phi_{k}\left(Y_{t-k}\right. \\
& \left.-Y_{t-k-1}\right)+e_{t} \\
& \Delta Y_{t}=a Y_{t-1}+\phi_{1} \Delta Y_{t-1}+. .+\phi_{k} \Delta Y_{t-k}+e_{t}
\end{aligned}
$$

Hipotesis awal pada pengujian ini adalah $a=0$ yang berarti bahwa $Y_{t}$ tidak stasioner. Hipotesis alternatif pada pengujian ini adalah $a<0$ yang berarti $Y_{t}$ stasioner (Chan dan Cryer [8]).

\section{Integrated Autoregressive Moving Average (ARIMA)}

ARIMA merupakan salah satu metode pemodelan univariat untuk memodelkan $d$ difference dimana $W_{t}=\Delta^{d} Y_{t}$ merupakan sebuah proses ARMA yang stasioner. $W_{t}$ mengikuti model $\operatorname{ARMA}(p, q)$ sehingga $Y_{t}$ merupakan proses $\operatorname{ARIMA}(p, d, q)$. Parameter $d$ yang secara umum digunakan dalam praktik adalah 1 atau paling banyak 2. $\operatorname{ARIMA}(p, 1, q)$ akan dirumuskan sebagai berikut (Chan dan Cryer [8]):

$W_{t}=\phi_{1} W_{t-1}+\phi_{2} W_{t-2}+\cdots+\phi_{p} W_{t-p}+e_{t}-\theta_{1} e_{t-1}$

$-\theta_{2} e_{t-2}-\cdots-\theta_{q} e_{t-q}$

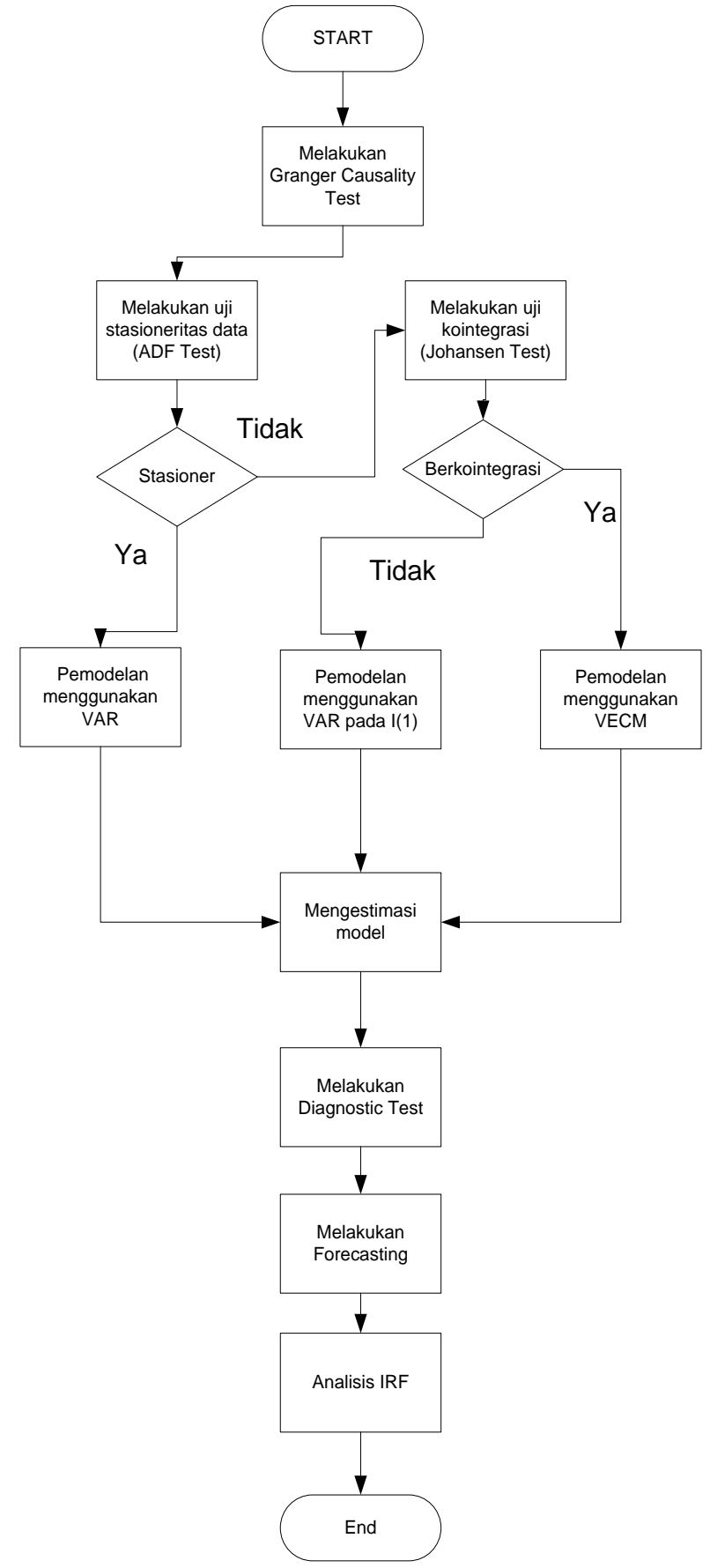

Gambar 1. Alur pemodelan multivariat time series.

\section{Pemodelan Multivariat Time Series}

Penentuan kausalitas antara variabel respon terhadap variabel prediktor merupakan langkah awal pada pemodelan multivariat time series. Pada penelitian ini causality test dilakukan dengan menggunakan Toda dan Yamamoto test. Selanjutnya prediktor yang memiliki relasi kausalitas dengan variabel respon akan dimodelkan dengan vector auto regressive (VAR). Bila tidak terjadi kointegrasi, maka model inilah yang akan digunakan. Namun, bila terjadi kointegrasi, maka perlu dilakukan koreksi terhadap error, untuk itu digunakan VECM. Di akhir pemodelan dilakukan analisis impulse 
response function (IRF) untuk melacak pengaruh dari suatu shock yang terjadi pada suatu variabel terhadap variabel-variabel lainnya. Alur penelitian ini dapat dilihat pada Gambar 1.

Secara ringkas metode-metode yang digunakan dapat dipaparkan sebagai berikut:

\section{Toda and Yamamoto Test}

Toda dan Yamamoto mengembangkan sebuah pengujian alternatif dari Granger causality test pada tahun 1995 yang dikenal dengan Toda and Yamamoto augmented Granger causality. Pengujian ini dapat digunakan pada data yang tidak stasioner pada level integrasi berapapun $I(m)$ serta pada data yang co-integrated maupun tidak. Pengujian ini berdasarkan pada persamaan sebagai berikut:

$X_{t}=\sum_{i=1}^{h+d} \beta_{i} X_{t-i}+\sum_{j=1}^{k+d} \alpha_{j} Y_{t-j}+\varepsilon_{t}$

Pada persamaan (4) $d$ menotasikan maximum order of integration, sedangkan $h$ dan $k$ merupakan panjang lag optimal yang didapatkan dari kriteria informasi. Hipotesis awal dari pengujian ini adalah $\mathrm{H}_{0}: \sum_{j=1}^{k+d} \alpha_{j}=0$ atau $Y$ tidak Granger-causes $\mathrm{X}$ (Bardarova and Josheski [9]).

\section{Vector Autoregressive Model}

Model ini merupakan multivariate time series model yang paling sering digunakan khususnya pada ekonometrik karena relatif mudah untuk diestimasi dan sifat-sifatnya telah banyak dipelajari dalam berbagai literatur. Model ini dinotasikan sebagai VAR(p) dan dimodelkan sebagai:

$Y_{t}=\phi_{0}+\sum_{i=1}^{p} \phi_{i} Y_{t-i}+e_{t}$

$\phi_{0}$ merupakan vektor berdimensi $k$ dan $\phi_{i}$ merupakan matriks $k \times k$ untuk $I>0, \phi_{p} \neq 0$, dan $e_{t}$ merupakan susunan vektor random positif yang identik dan independen dengan mean 0 dan matriks kovarians $\sum e$. Model ini dapat dilakukan apabila data time series yang akan digunakan bersifat stasioner (Tsay [10]).

\section{Kointegrasi}

Data time series yang tidak stasioner dapat mengandung kointegrasi. Data non stasioner yang tidak mengandung kointegrasi dapat dimodelkan dengan menggunakan VAR dengan terlebih dahulu melakukan difference. Data time series non stasioner yang mengandung kointegrasi tidak dapat dimodelkan menggunakan VAR karena akan menghasilkan spurious regression. Data tersebut dapat dimodelkan menggunakan VECM.

$\beta^{\prime} Y_{t}=\beta_{1} y_{1 t}+\ldots+\beta_{n} y_{n t} \sim I(0)$
$Y_{t}=\left(y_{1 t}, \ldots, y_{n t}\right)^{\prime}$ menotasikan $(n \times 1)$ vektor yang terintegrasi pada orde pertama $(I(1)) . Y_{t}$ disebut berkointegrasi apabila terdapat $(n \times 1)$ vektor $\beta=\left(\beta_{1}, \ldots, \beta_{n}\right)^{\prime}$ dan kombinasi linier dari vektor $Y_{t}$ dan $\beta$ stasioner atau $I(0)$. Vektor $\beta$ disebut juga dengan vektor pengkointegrasi (cointegrating vector).

Jika $(n \times 1)$ vektor $Y_{t}$ terkointegrasi, maka akan terdapat $0<r<n$ cointegrating vector yang independen secara linier dimana $r$ menotasikan derajat kointegrasi (rank of cointegration). Pengujian akan nilai $r$ dapat dilakukan menggunakan Johansen procedure (Wang dan Zivot [11]).

\section{Vector Error Correction Model}

Data time series yang non stasioner dan berkointegrasi dapat dimodelkan dengan menggunakan VECM seperti pada (6);

$\Delta Y_{t}=\Pi Y_{t-1}+\Gamma_{1} \Delta Y_{t-1}+\Gamma_{2} \Delta Y_{t-2}+\ldots+$

$\Gamma_{p-1} \Delta Y_{t-p+1}+\varepsilon_{t}$

$\Delta Y_{t}$ merupakan vektor $(n \times 1)$ difference dari suatu data time series, $\Pi$ merupakan matriks $(n \times n)$ yang merupakan hasil perkalian antara matriks $(n \times r)$ adjustment coefficient $(\alpha)$ dengan matriks $(r \times n)$ vektor pengkointegrasi $\beta$ (Wang and Zivot [11]).

\section{Johansen Procedure}

Johansen memformulasikan suatu likelihood ratio (LR) statistics untuk menentukan rank dari matriks $\Pi$, pengujian ini berdasarkan nilai estimasi dari eigen values dari matriks $\Pi$. Johansen Procedure mula-mula akan menguji apakah terdapat kointegrasi pada data. Hipotesis awal dari pengujian ini adalah tidak terdapat kointegrasi $(r=0)$ pada data dan hipotesis alternatif dari pengujian ini adalah terdapat kointegrasi pada data $(r>0)$.

Perhitungan nilai statistik dari pengujian ini dihitung menggunakan (7) dan kemudian akan dibandingkan dengan critical value. Nilai statistik yang lebih kecil dari critical value menyatakan bahwa hipotesis awal diterima.

$L R=-T \sum_{i=r_{0}+1}^{n} \ln (1-\hat{\lambda} i)$

Penolakan hipotesis awal menandakan bahwa terdapat kointegrasi $(r>0)$, sehingga pengujian dilanjutkan dengan menguji apakah nilai $r=1$ dan seterusnya hingga hipotesis awal ditolak (Wang dan Zivot [11]).

\section{Impulse Response Function}

Impulse response function (IRF) merupakan suatu pendekatan untuk melihat relasi antar variabel. 
Impulse response merupakan suatu fungsi dinamis untuk melacak pengaruh dari suatu shock yang terjadi pada suatu variabel terhadap variabel-variabel lainnya. IRF menghitung besarnya perubahan yang akan dialami oleh semua variabel pada $t>0$ apabila terdapat perubahan/shock pada 1 variabel pada saat $t=0$. Asumsi pada perhitungan IRF adalah $E\left(Z_{t}\right)=0$ dikarenakan mean tidak berpengaruh terhadap pergerakan respon $Y_{t}$ akibat shock.

Secara matematis, tujuan dari IRF adalah untuk mencari tahu pengaruh dari perubahan $y_{i t}$ terhadap $y_{t+j}$ utuk $j>0$ dimana setiap elemen lain tidak berubah sehingga dapat diasumsikan bahwa $t=0$, $y_{t}=0$ untuk $t \leq 0$, dan $a_{0}=(1,0,0, \ldots)^{\prime}$. Nilai dari $y_{t}$ untuk $t>0$ dapat dicari menggunakan representasi MA $(\theta)$ dari model VAR $(p)$ (Tsay [10]).

$$
\begin{aligned}
& y_{0}=a_{0}=\left[\begin{array}{c}
1 \\
0 \\
\vdots \\
0
\end{array}\right], \quad y_{1}=\theta_{1} a_{0}=\left[\begin{array}{c}
\theta_{1,11} \\
\theta_{1,21} \\
\vdots \\
\theta_{1, k 1}
\end{array}\right], \\
& y_{2}=\theta_{2} a_{0}=\left[\begin{array}{c}
\theta_{2,11} \\
\theta_{2,21} \\
\vdots \\
\theta_{2, k 1}
\end{array}\right], \cdots
\end{aligned}
$$

\section{Hasil dan Pembahasan}

\section{Data}

Data yang akan dipergunakan dalam penelitian ini adalah harga emas, harga minyak mentah, tingkat inflasi di Amerika, indeks US Dollar, dan Index Dow Jones dari bulan Juni tahun 2007 hingga bulan Oktober tahun 2016. Data-data tersebut merupakan variabel-variabel yang diyakini berpengaruh terhadap harga emas.

Sepanek [5] mengatakan bahwa US Dollar dan tingkat inflasi berpengaruh terhadap harga emas. US Dollar merupakan salah satu alternatif investasi seseorang disamping emas. US Dollar dan emas secara umum diyakini memiliki korelasi negatif dimana harga emas akan naik seiring dengan melemahnya US Dollar. Inflasi mendorong pelaku ekonomi untuk menukarkan uang dengan emas dikarenakan inflasi merujuk pada melemahnya nilai mata uang sebagai substitusi dari investasi emas.

Index Dow Jones sebagai salah satu bursa saham terbesar di dunia merupakan refleksi dari kondisi politik dan ekonomi sebagai salah satu faktor yang mempengaruhi harga emas. Riset yang dilakukan oleh Gilroy [7] menyatakan bahwa harga minyak berpengaruh terhadap harga emas, sehingga harga minyak akan digunakan sebagai salah satu faktor yang akan dianalisis pula pada penelitian ini.
Tabel 1. Sumber data penelitian

\begin{tabular}{llll}
\hline Variabel & Data & \multicolumn{1}{c}{ Satuan } & Sumber \\
\hline Emas & \multicolumn{1}{l}{ Harga Emas USD/Troy } & jmbullion.com \\
& JM Bullion & Ounce & \\
US Dollar & Indeks USD - & jmbullion.com \\
Saham & Indeks Dow - & jmbullion.com \\
& Jones & & \\
Inflasi & Tingkat $\quad$ Persentase Usinflationcalculator. & com \\
& Inflasi di & & \\
& Amerika & & \\
Minyak & Crude Oil & USD / & macrotrends.net \& \\
Mentah & NYMEX/ & Barrel & Bloomberg \\
& WTI & & \\
\hline
\end{tabular}

Dugaan adanya relasi antara harga emas dan faktor-faktor tersebut akan dibuktikan menggunakan multivariate time series analysis pada bagian lain dari penelitian ini. Variabel US Dollar dan saham pada penelitian ini akan digambarkan melalui data time series dari indeks US Dollar dan indeks Dow Jones. Variabel emas dan minyak akan dimodelkan menggunakan data harga emas dan minyak mentah. Variabel inflasi akan digambarkan melalui data tingkat inflasi di Amerika. Data pada semua variabel merupakan data runtut waktu bulanan (monthly data) dengan penjelasan lengkap yang dapat dilihat pada Tabel 1 .

\section{Pemodelan dengan Menggunakan Univariat Time Series.}

Pemodelan univariat merupakan pemodelan terhadap suatu variabel dengan hanya menggunakan variabel itu sendiri. Hasil pemodelan univariat merupakan salah satu dasar dalam melakukan pemodelan multivariat. Hasil pemodelan univariat dapat digunakan dalam menentukan variabel yang berpengaruh (Granger causes) dalam pemodelan multivariat. Variabel/ faktor lain selain harga emas dapat meningkatkan akurasi dari peramalan jika hasil peramalan menggunakan penambahan faktor tersebut lebih baik dari pada peramalan tanpa adanya faktor tersebut (pemodelan univariat). Pembahasan mengenai fungsi tersebut akan dibahas pada bagian lain dari penelitian ini.

Terdapat beberapa model peramalan univariat yang akan digunakan pada penelitian ini. Model-model tersebut adalah auto regressive (AR), moving average (MA), auto regressive moving average (ARMA), dan integrated auto regressive moving average (ARIMA). Pemilihan penggunaan model dalam pemodelan univariat bergantung pada karakteristik dari data yang akan diolah.

Model-model peramalan AR, MA, dan ARMA hanya dapat diterapkan pada data time series yang bersifat stasioner sedangkan model peramalan ARIMA dapat digunakan untuk memodelkan data time series yang tidak stasioner. 


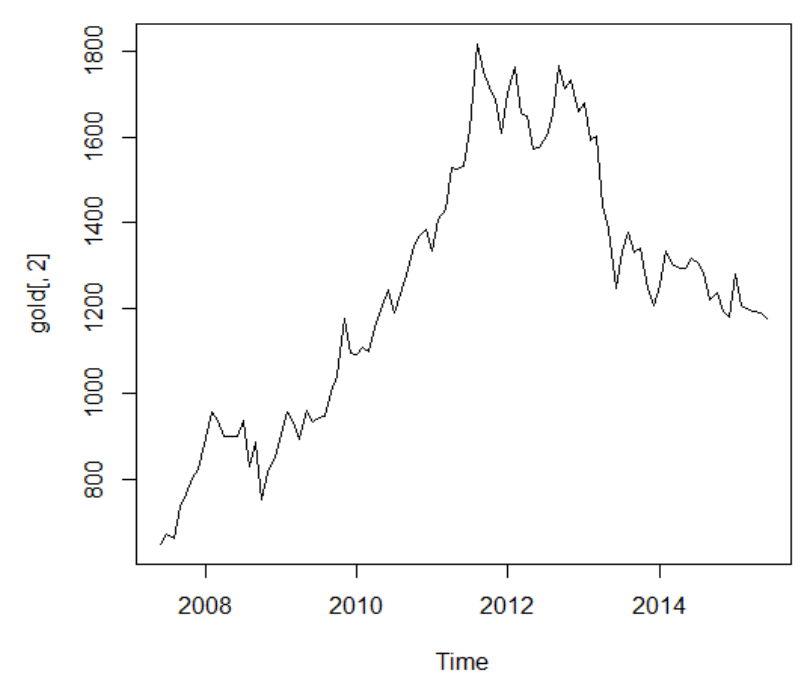

Gambar 2. Plot harga emas

Data disebut stasioner jika memiliki mean dan variance yang konstan. Plot harga emas dari bulan Juni 2007 hingga Juni 2015 dalam satuan per US Dollar per troy ounce dapat dilihat pada Gambar 2 .

Pengujian mengenai stasioneritas secara lebih jelas dapat dilakukan menggunakan augmented Dicky Fuller test. Hipotesis pengujian ini adalah:

$H_{0}$ : Data tidak stasioner (mengandung unit roots)

$H_{1}$ : Data stasioner.

Hasil pengujian ADF dengan menggunakan software $\mathrm{R}$, didapatkan bahwa nilai ADF sebesar 0,56 dan $p$-value $=0,98$. Hal ini menyatakan bahwa hipetesis awal dari tes ini gagal tolak, sehingga dapat dikatakan bahwa harga emas bersifat tak stasioner atau memiliki unit roots lebih dari 1 . Pemodelan univariat dari harga emas selanjutnya dilakukan dengan menggunakan model ARIMA (p,d,q). Menggunakan Akaike information criterion (AIC), diperoleh bahwa model terbaik untuk harga emas tersebut adalah $\operatorname{ARIMA}(0,1,0) \cdot \operatorname{ARIMA}(0,1,0)$ menunjukkan bahwa fluktuasi harga emas merupakan white noise setelah mengalami difference yang pertama. Sifat fluktuasi harga emas sebagai white noise berarti bahwa pergerakan harga emas tidak dapat diprediksi apabila dimodelkan menggunakan nilainya sendiri. Harga emas sebagai sebuah white noise juga merupakan temuan dari penelitian Botha[3] serta Shankari dan Manimaran [4].

\section{Pemodelan dengan Menggunakan Multivariat Time Series.}

Pemodelan multivariat harga emas merupakan pemodelan harga emas dengan harga emas dan variabel-variabel lain yang berpengaruh sebagai prediktor. Penelitian ini akan mencoba untuk menggunakan indeks US Dollar, indeks Dow Jones, harga minyak, dan tingkat inflasi dalam memodel- kan harga emas. Variabel-variabel yang akan digunakan untuk memodelkan harga emas hanyalah variabel yang teruji berpengaruh terhadap harga emas. Pengujian tersebut akan dilakukan menggunakan Granger causality test.

Pengujian Granger causality kemudian dilakukan dengan menggunakan Toda Yamamoto augmented Granger causality test. Pengujian ini memiliki hipotesis awal yang menyatakan bahwa variabel-variabel tersebut tidak berpengaruh terhadap emas dan hipotesis alternatif bahwa variabel-variabel tersebut berpengaruh (Granger causes) terhadap harga emas. Hasil pengujian ini dapat dilihat pada Tabel 2.

Hasil pengujian menunjukkan bahwa indeks USD, indeks Dow Jones, harga minyak mentah (crude oil), dan tingkat inflasi di Amerika Granger causes terhadap harga emas. Hasil pengujian menunjukkan bahwa pemodelan dengan menambahkan variabel-variabel tersebut dapat membuat peramalan harga emas menjadi lebih akurat. Hasil pengujian ini berarti bahwa semua variabel tidak perlu dibuang dan dapat digunakan untuk memodelkan harga emas.

Pemodelan menggunakan VAR dapat dipergunakan apabila data bersifat stasioner. Berdasarkan pengujian $\mathrm{ADF}$, telah diketahui bahwa variabelvariabel yang akan dimodelkan bersifat tidak stasioner sehingga memodelkan data secara langsung dengan menggunakan model VAR tidak dapat dilakukan karena akan menyebabkan munculnya spurious regression. Data yang tidak stasioner dapat dimodelkan menggunakan VAR setelah melakukan difference yang pertama apabila data tidak berkointegrasi. Data yang tidak stasioner dan berkointegrasi dapat dimodelkan menggunakan VECM.

Pengujian kointegrasi pada penelitian ini dilakukan menggunakan Johansen cointegration test. Pengujian ini bertujuan untuk mengetahui adanya kointegrasi pada data serta mengetahui jumlah rank $(r)$ yang mengindikasikan banyaknya vektor pengkointegrasi (cointegrating vector). Jumlah rank maksimal adalah $n-1$ dimana $n$ adalah banyaknya variabel (dalam penelitian ini 5). Hipotesis awal pada pengujian ini adalah $r=0$ dimana tidak terdapat kointegrasi dan hipotesis alternatifnya terdapat kointegrasi $(r>0)$. Penolakan terhadap hipotesis awal $(r=0)$ akan dilanjutkan dengan pengujian untuk menentukan rank (banyaknya vektor pengkointegrasi).

Tabel 2 Hasil pengujian Granger causality

\begin{tabular}{ccccc}
\hline & USD & Dow Jones & Crude Oil & US Inflation \\
\hline$P$-Value & 0,02492 & 0,000381 & 0,01999 & 0,02472 \\
\hline
\end{tabular}


Hasil pengujian menggunakan Johansen procedure menunjukkan bahwa data berkointegrasi karena hipotesis awal $r=0$ ditolak. Hasil pengujian menunjukkan bahwa jumlah rank adalah 2 yang berarti terdapat 2 cointegrating vector yang akan digunakan untuk memodelkan data menggunakan VECM. Kesimpulan tersebut didapatkan setelah prosedur ketiga dengan hipotesis awal $r=2$ diterima. Jumlah rank sebanyak 2 berarti kombinasi linier 2 vektor pengkointegrasi dengan variabelvariabel bersifat stasioner. Selanjutnya dilakukan pemodelan dengan menggunakan VECM. Estimasi parameter dalam pemodelan didapatkan dengan menggunakan bantuan software R. Bentuk model VECM dapat dilihat pada (7).

$\left[\begin{array}{c}\Delta \text { Gold }_{t} \\ \Delta D J_{t} \\ \Delta \text { Crude }_{t} \\ \Delta \$_{t} \\ \Delta I_{t}\end{array}\right]=\alpha \beta\left[\begin{array}{c}\text { Gold }_{t-1} \\ D_{t-1} \\ \text { Crude }_{t-1} \\ \$_{t-1} \\ I_{t-1}\end{array}\right]+\Gamma_{1}\left[\begin{array}{c}\Delta \text { Gold }_{t-1} \\ \Delta D J_{t-1} \\ \Delta \text { Crude }_{t-1} \\ \Delta \$_{t-1} \\ \Delta I_{t-1}\end{array}\right]+\Gamma_{2}\left[\begin{array}{c}\Delta \text { Gold }_{t-2} \\ \Delta D J_{t-2} \\ \Delta \text { Crude }_{t-2} \\ \Delta \$_{t-2} \\ \Delta I_{t-2}\end{array}\right]$ + Const

dimana

Const $=\left[\begin{array}{c}302,6 \\ 5.788 \\ 154,8 \\ -8,48 \\ 4,55\end{array}\right], \alpha=\left[\begin{array}{cc}-2,110^{-3} & 2,710^{-3} \\ 3,610^{-1} & 7,910^{-2} \\ 3,910^{-3} & 1,710^{-3} \\ -6,310^{-4} & -1,210^{-4} \\ 2,210^{-4} & 5,810^{-5}\end{array}\right]$

$\beta=\left[\begin{array}{ccccc}1 & 0 & 78,58 & 12,27 & -1271,98 \\ 0 & 1 & -465,31 & -1001,9 & 2901,1\end{array}\right]$

$\Gamma_{1}=\left[\begin{array}{ccccc}-0,15 & 1,5410^{-3} & -1,74 & -6,24 & 20,23 \\ -1,26 & -0,29 & 0,51 & -24,31 & -209,9 \\ -3,110^{-2} & -1,310^{-3} & -0,18 & -1,57 & -0,92 \\ 2,310^{-3} & 6,710^{-4} & 5,110^{-2} & 1,710^{-2} & 0,93 \\ 6,410^{-4} & 4,710^{-5} & 7,910^{-3} & -6,210^{-2} & 0,24\end{array}\right]$

$\Gamma_{2}=\left[\begin{array}{ccccc}-2.310^{-2} & 2,310^{-3} & -1,48 & -6,96 & -1,175 \\ 1,02 & -0,17 & 6,32 & -0,26 & -2.610^{-2} \\ 3.710^{-3} & 1,0210^{-3} & -0,12 & -1,38 & -1,33 \\ -2,210^{-3} & 1,410^{-3} & 4,0210^{-2} & 0,22 & 0,52 \\ -6,410^{-5} & -5,510^{-2} & -8,210^{-3} & -6,310^{-2} & -0,12\end{array}\right]$

Gold menotasikan harga emas, DJ menotasikan indeks Dow Jones, Crude menotasikan harga minyak mentah, \$ menotasikan indeks US Dollar, dan I menotasikan tingkat inflasi di Amerika. Const merupakan vektor konstan yang menotasikan nilai mean, $\alpha$ merupakan matriks (5 $x 2$ ) yang menotasikan koefisien penyesuaian, $\beta$ merupakan matriks $(2 x 5)$ yang menotasikan vektor pengkointegrasi. Vektor pengkointegrasi merupakan hubungan kesetimbangan (equilibrium) jangka panjang diantara variabel dan koefisien penyesuaian merupakan kecepatan dari koreksi terhadap error guna mencapai kesetimbangan pada satu periode. $\Gamma_{1}$ dan $\Gamma_{2}$ merupakan matriks (5 $x 5$ ) yang berisikan koefisien autoregressive pada lag pertama dan kedua.

Pengujian terhadap residual (diagnostic test) dan peramalan model dilakukan dengan terlebih dahulu mentransformasikan model kedalam bentuk VAR. Diagnostic Test dilakukan untuk memastikan apakah model yang dibentuk telah valid dan dapat digunakan untuk melakukan peramalan. Hasil transformasi model kedalam bentuk VAR dapat dilihat pada (8).

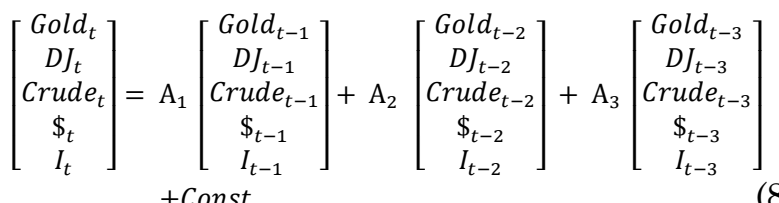

dimana

$A_{1}=\left[\begin{array}{ccccc}0,85 & 1,5410^{-3} & -1,74 & -6,24 & 20,23 \\ -1,26 & 0,708 & 0,51 & -24,31 & -209,99 \\ -3,110^{-2} & -1.310^{-3} & 0,81 & -1,57 & -0,92 \\ 2,310^{-3} & 6,710^{-4} & 5,110^{-2} & 0,98 & 0,93 \\ 6,410^{-4} & 4,710^{-5} & 7,910^{-3} & -6,210^{-2} & 1,24\end{array}\right]$

$A_{2}=\left[\begin{array}{lllcr}0,123 & 8,310^{-3} & 0,25 & -0,723 & -21,4 \\ 2,29 & 0,117 & 5,809 & -1,79 & -59,27 \\ 0,035 & 2,310^{-3} & 0,054 & 0,191 & -0,408 \\ -4,510^{-3} & 7,510^{-4} & 0,011 & 0,238 & -0,402 \\ -710^{-4} & 110^{-4} & -0,01 & -5,610^{-3} & -0,36\end{array}\right]$

$\left[\begin{array}{ccccc}0,021 & 3,410^{-4} & 0,049 & 4,203 & 11,78 \\ -0,66 & 0,252 & -14,72 & -48,4 & 40,35\end{array}\right.$

$A_{3}=\mid \begin{array}{lllll}-0,66 & 0,252 & -14,72 & -48,4 & 40,35 \\ 1,110^{-4} & 7,210^{-4} & -0,38 & -0,327 & 1,446\end{array}$

$\begin{array}{ccccr}1,110 & & & & \\ 1,510^{-3} & -1,510^{-3} & 0,048 & -0,1 & -0,08 \\ 2,810^{-4} & 1,110^{-3} & -1,610^{-3} & 7,410^{-3} & 0,015\end{array}$

Const $=\left[\begin{array}{c}302,6 \\ 5.788 \\ 154,8 \\ -8,48 \\ 4,55\end{array}\right]$

Hasil konversi model VECM menjadi VAR dengan model VAR(3) dimana Const pada (8) merupakan vektor konstan ( $5 x 1$ ) yang menotasikan mean sedangkan $A_{1}, A_{2}$, dan $A_{3}$ merupakan matriks (5 x 5) yang berisikan koefisien autoregressive pada lag pertama, kedua, dan ketiga.

Selanjutnya akan dilakukan diagnostic test yang terdiri dari serial correlation test, heteroscedasticity test, dan normality test pada residual model. Diagnostic test diperlukan sebagai validasi untuk memastikan bahwa error dari model telah mengikuti asumsi IIDN.

Pengujian serial correlation dilakukan mengunakan portmanteau test. Hipotesa awal dari pengujian ini adalah data tidak berkorelasi secara serial. Hasil pengujian menunjukkan bahwa residual tidak berkorelasi secara serial ( $p$-value $=0,196)$. Heteroscedasticity test dilakukan dengan menggunakan ARCHLM test dengan hipotesa awal data bersifat identik (homoscedasticity). Hasil pengujian menunjukkan bahwa residual model bersifat identic ( $p$-value = 0,3265). Pengujian normalitas residual dilakukan menggunakan Jarque-Bera test dengan hipotesa awal residual berdistribusi normal dengan skewness 0 dan nilai kurtosis 3 . Hasil pengujian menunjukkan bahwa residual telah berdistribusi normal ( $p$-value $=$ 0,159). Hasil diagnostic test menunjukkan bahwa residual model telah memenuhi asumsi IIDN sehingga model telah tervalidasi dan dapat digunakan untuk mela-kukan peramalan. 
Tabel 3. Hasil peramalan

\begin{tabular}{lrrrrr}
\hline Tanggal & \multicolumn{1}{c}{ Forecast } & Lower CI & Upper CI & \multicolumn{1}{l}{ Actual } & \multicolumn{1}{c}{ Error } \\
\hline Jul-15 & $1.186,17$ & $1.070,19$ & $1.302,15$ & $1.098,79$ & 87,38 \\
Aug-15 & $1.193,97$ & $1.034,36$ & $1.353,58$ & $1.136,23$ & 57,74 \\
Sep-15 & $1.199,05$ & 997,81 & $1.400,29$ & $1.137,46$ & 61,59 \\
Oct-15 & $1.206,25$ & 968,54 & $1.443,96$ & $1.153,20$ & 53,05 \\
Nov-15 & $1.213,26$ & 940,57 & $1.485,94$ & $1.068,28$ & 144,9 \\
Dec-15 & $1.219,87$ & 915,54 & $1.524,19$ & $1.074,01$ & 145,86 \\
Jan-16 & $1.226,16$ & 892,69 & $1.559,63$ & $1.118,10$ & 108,06 \\
Feb-16 & $1.231,94$ & 871,40 & $1.592,48$ & $1.223,78$ & 8,16 \\
Mar-16 & $1.237,30$ & 851,43 & $1.623,18$ & $1.229,86$ & 7,44 \\
Apr-16 & $1.242,31$ & 832,51 & $1.652,10$ & $1.258,21$ & $-15,90$ \\
May-16 & $1.247,23$ & 814,56 & $1.679,89$ & $1.222,77$ & 24,46 \\
Jun-16 & $1.252,07$ & 797,37 & $1.706,78$ & $1.282,11$ & $-30,03$ \\
Jul-16 & $1.256,96$ & 780,91 & $1.733,00$ & $1.336,90$ & $-79,93$ \\
Aug-16 & $1.261,88$ & 765,12 & $1.758,64$ & $1.325,30$ & $-63,41$ \\
Sep-16 & $1.266,86$ & 749,94 & $1.783,77$ & $1.332,58$ & $-65,71$ \\
Oct-16 & $1.271,86$ & 735,35 & $1.808,36$ & $1.270,52$ & 1,34 \\
\hline Mean Actual & \multicolumn{7}{c}{} & & $1.204,25$ & RMSE \\
\hline
\end{tabular}

\section{Harga Emas}

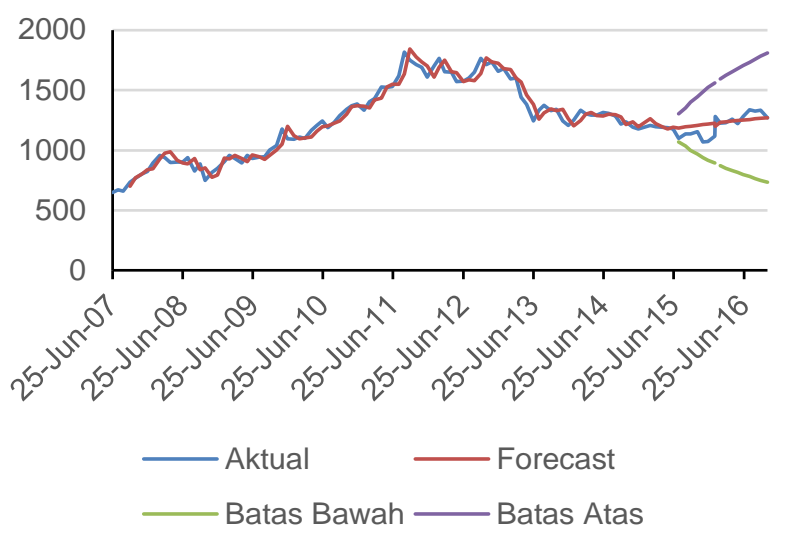

Gambar 3. Grafik harga emas

Model dibangun menggunakan data periode Juni 2007 hingga Juni 2015. Peramalan harga emas pada Tabel 3 merupakan peramalan untuk periode Juli 2015 hingga Oktober 2016 yang akan dibandingkan terhadap harga aktual emas. Hasil peramalan dapat dilihat pada kolom Forecast sedangkan data harga emas aktual dapat dilihat pada kolom Actual. Hasil peramalan menunjukkan adanya tren peningkatan harga emas hingga Oktober 2016, sedangkan harga aktual emas mengalami peningkatan secara long run, namun mengalami penurunan pada November 2015, Mei 2016, Agustus 2016, dan Oktober 2016. Hasil peramalan menggunakan model yang telah dibangun menunjukkan bahwa nilai aktual harga emas berada pada 95\% Confidence Interval hasil peramalan model. RMSE dari peramalan sebesar 74,2 atau $6,1 \%$ dari mean harga emas aktual. Hasil ini menunjukkan bahwa model peramalan telah dibangun dengan baik dan menunjukkan hasil yang cukup akurat.

Hasil peramalan menggunakan model yang telah dibangun ditunjukkan melalui garis merah pada
Gambar 3. Harga aktual emas ditunjukkan melalui garis biru, sedangkan batas bawah dan batas atas dari peramalan harga emas ditunjukkan melalui garis abu-abu dan jingga. Grafik peramalan menunjukkan bahwa hasil peramalan berada pada Confidence Interval.

\section{Impulse Response Function}

Granger causality test menyatakan bahwa variabel Dow Jones, US Dollar, US Inflation, dan Crude Oil membantu dalam memprediksi harga emas, namun seberapa besar dan arah dari pengaruh masingmasing variabel tidak diketahui. Pengaruh dari setiap elemen dapat diketahui menggunakan analisis Impulse Response Function (IRF). Impulse Response Function menghitung besarnya perubahan yang akan dialami oleh semua variabel pada $t>0$ apabila terdapat perubahan/ shock pada salah 1 variabel pada saat $t=0$. Hasil perhitungan Impulse Response Function untuk 10 lag kedepan dengan harga emas sebagai respon dapat dilihat pada Tabel 4.

Tabel 4 menunjukkan respon harga emas pada 10 periode kedepan pada setiap peningkatan sebesar 1 poin oleh variabel-variabel lain dan dirinya sendiri. Hasil perhitungan IRF menunjukkan bahwa peningkatan indeks US Dollar pada saat ini sebesar 1 poin akan diikuti dengan penurunan harga emas sebesar \$ 6,24 per troy ounce pada 1 bulan kedepan, $\$ 10,75$ pada 2 bulan dari sekarang, dan penurunan sebesar $\$ 12,3$ pada 10 bulan dari sekarang. Peningkatan tingkat inflasi sebesar $1 \%$ pada saat ini akan meningkatkan harga emas sebesar $\$ 20,2$ pada 1 bulan dari sekarang dan $\$ 52,8$ pada 10 bulan kedepan. Peningkatan harga minyak sebesar 1 dollar pada saat ini akan menurunkan harga emas sebesar 1,73 dollar pada bulan depan dan 3,43 dollar 10 bulan dari sekarang. Peningkatan indeks Dow Jones sebesar 1 poin pada saat ini akan mengakibatkan harga emas meningkat pada bulan pertama dan kedua di masa yang akan datang, namun akan menurunkan harga emas setelah 2 bulan.

Tabel 4. Impulse response function

\begin{tabular}{clrrrr}
\hline Lag & Gold & \multicolumn{2}{c}{ Dow Jones } & Crude Oil & \multicolumn{2}{c}{ USD } & $\begin{array}{c}\text { US } \\
\text { inflation }\end{array}$ \\
\hline 1 & 0,8529 & 0,0015 & $-1,7375$ & $-6,2410$ & 20,2293 \\
2 & 0,9016 & 0,0022 & $-2,1688$ & $-10,7522$ & 16,4307 \\
3 & 0,9029 & $-0,0103$ & $-2,8751$ & $-12,1128$ & 19,4323 \\
4 & 0,9479 & $-0,0118$ & $-3,0648$ & $-12,7388$ & 24,1471 \\
5 & 0,9387 & $-0,0108$ & $-3,4577$ & $-13,2747$ & 31,5574 \\
6 & 0,9473 & $-0,0124$ & $-3,3839$ & $-12,8244$ & 36,5892 \\
7 & 0,9456 & $-0,0140$ & $-3,4066$ & $-12,6043$ & 41,7918 \\
8 & 0,9455 & $-0,0132$ & $-3,3758$ & $-12,3614$ & 46,1491 \\
9 & 0,9409 & $-0,0134$ & $-3,4124$ & $-12,3356$ & 49,9273 \\
10 & 0,9423 & $-0,0136$ & $-3,4334$ & $-12,3023$ & 52,8193 \\
\hline
\end{tabular}


Hasil analisis melalui impulse response function menunjukkan bahwa indeks USD dan harga Crude Oil memiliki korelasi negatif terhadap harga emas, sedangkan tingkat inflasi memiliki korelasi positif dengan harga emas. Indeks Dow Jones memiliki korelasi positif dengan emas pada periode pertama dan kedua pada masa yang akan datang, dan memiliki korelasi negatif setelahnya. Korelasi negatif antara USD dan emas menunjukkan bahwa pelemahan USD akan mendorong pelaku ekonomi untuk menyimpan uang nya dalam bentuk emas guna mempertahankan daya beli. Korelasi positif harga emas dan inflasi menunjukkan bahwa nilai dari emas tidak tergerus oleh inflasi, sehingga mendukung pernyataan investasi emas disebut mampu menahan gejolak inflasi (Kusuma [2]).

\section{Simpulan}

Pemodelan univariat harga emas menunjukkan bahwa harga emas mengikuti model $\operatorname{ARIMA}(0,1,0)$ yang berarti fluktuasi harga emas merupakan white noise. Fakta tersebut menyatakan bahwa harga emas tidak dapat dimodelkan hanya dengan menggunakan data historisnya sendiri. Fakta penelitian ini didukung oleh temuan serupa oleh J.P. Botha [3] serta Shankari dan Manimaran [4].

Pemodelan multivariat untuk memodelkan harga emas dilakukan menggunakan Vector Error Correction Model (VECM) dikarenakan variabel-variabel yang digunakan bersifat nonstasioner dan berkointegrasi. Hasil penelitian menunjukkan bahwa harga emas dipengaruhi oleh indeks US Dollar, indeks Dow Jones, harga minyak mentah, dan tingkat inflasi. Indeks US Dollar dan harga minyak mentah memiliki korelasi negatif terhadap harga emas, sedangkan tingkat inflasi berkorelasi positif dengan harga emas. Indeks Dow Jones berkorelasi positif dengan harga emas hanya pada lag pertama dan kedua.

\section{Daftar Pustaka}

1. Holmes, F., Top 10 Countries with The Largest Gold Reserves, Forbes, May 26, 2016.

2. Kusuma, D. M., Ini Keuntungan Investasi Emas Batangan dalam 2 Tahun, Detik Finance, 26 September 2015.

3. Botha, J. P., The Random Walk Model and The Behaviour of Gold Price: A Note, Investment Analysts Journal, 9(15), 1980, pp. 19-23.

4. Manimaran, S., and Shankari, S., An Empirical Investigation of Random Walks in Gold Price Movement, Global Journal of Commerce and Management Prespective, 4(2), 2015, pp. 16-21.

5. Sepanek, E., How These 10 Factors Regulary Influence Gold Prices. Scottsdale. Retrieved from http://www.sbcgold.com/blog/10-factorsregularly-influence-gold-prices/ on 25 July 2016.

6. Sahabat Penggadaian, 5 Faktor yang Mempengaruhi Harga Emas Naik dan Turun. Sahabat Pegadaian. Retrieved from http://sahabatpegadaian.com/emas/5-faktor-harga-emas-naik-danturun on 25 July 2016.

7. Gilroy, A., Why Gold and US Dollar have an Inverse Relationship, Market Realist, September 24, 2014.

8. Chan, K. S., \& Cryer, J. D. Time Series Analysis With Applications in R. New York, Springer, 2008.

9. Bardarova, S. and Josheski, D., Causal Relationship between Wages and Prices in R. Macedonia: VECM Analysis. Munich Personal RePEc Achieve, 2013.

10. Tsay, R.S. Multivariate Time Series Analysis With $R$ and Financial Applications. New Jersey, Wiley, 2014.

11. Wang, J., and Zivot, E., Modeling Financial Time Series with S-Plus, Second Edition. New York, Springer, 2006. 